\title{
Post Consolidation Asset Base: Effect on Financial Leverage, Efficiency and Profitability of Nigerian Banks
}

\author{
Daibi W. Dagogo ${ }^{1} \&$ Precious I. Okorie ${ }^{1}$ \\ ${ }^{1}$ Department of Banking and Finance, Rivers State University of Science and Technology, Port Harcourt, Nigeria \\ Correspondence: Daibi W. Dagogo, Department of Banking and Finance, University of Science and Technology, \\ Rivers State, Port Harcourt, Nigeria. Tel: 803-405-4408. Email: dagogo.daibi@ust.edu.ng or \\ daibidagogo@yahoo.com
}

Received: July 14, 2014

Accepted: August 19, 2014

Online Published: September 25, 2014

doi:10.5539/ijef.v6n10p280

URL: http://dx.doi.org/10.5539/ijef.v6n10p280

\begin{abstract}
This paper examines the effect of post-bank consolidation on financial leverage, asset efficiency and profitability of Nigerian banks. Cross-sectional and time series data were collected from Nigerian Stock Exchange fact books and annual reports and accounts of various banks, specifically on revenue, fixed assets, long term debt, and profit after tax. Leverage, assets efficiency and profitability ratios were calculated and the data delineated into two eras: pre-consolidation era (involving 30 banks) and post-consolidation era (with 16 banks). Paired sample t-test of mean and multiple regression analysis were employed to evaluate bank performance. Financial leverage was lower in the post-consolidation era indicating lower risk, lesser vulnerability and greater stability. Assets efficiency and profitability were not significantly different in both eras. Again the multiple regression analysis shows stronger explanatory power of asset efficiency to cause changes in financial leverage for both pre-and post-consolidation eras than that of profitability, albeit in contrast to a priori expectation. The anxieties expressed by industry watchers that the dusts are not yet settled with Nigeria's banks credibility are therefore founded in empirical results.
\end{abstract}

Keywords: financial leverage, bank consolidation, bank stability

\section{Introduction}

\subsection{Background of the Study}

The highest point of Professor Charles Soludo's regime as governor of Central Bank of Nigeria (CBN) is the consolidation of Nigerian banking sector to meet the challenges of the twenty-first century. The effect of this programme on the economy could only be compared with the economic baseline that bred and nurtured this same unsound banking institution we saw as problem. That was the introduction of structural adjustment programme (SAP) in 1986 as a call to eliminate both internal and external imbalances through the institutionalization of a market-based economy. One of the pillars of SAP was financial liberalization, which is the efficient allocation of financial resources through the interaction of the market forces of demand and supply, this time to determine the demand, supply and cost of capital (Ollor, 2008). It was a remarkable departure from administrative fiat, and was thought to have the capacity to eliminate several bottlenecks faced by the private sector operators in their bid to access funds for industrialization. It was also noted that financial liberalization enhanced growth of financial institutions that provided funds to investors because it is a movement from a system of controlled interest rates to that of flexible interest rates. It was therefore designed to facilitate adequate savings mobilization and encourage efficiency in the allocation of financial resources by the licensing of more banks, even though the monetary authorities were no less liberal on the conditions for granting license (Aderibigbe, 1997). Not surprising, the number of commercial and merchant banks increased from 41 in 1986 to 119 in 1991. This increase, while in line with the objective of improved competitive banking environment and efficiency in financial intermediation, provided scope for increased attention on regulation and supervision by the monetary authorities. Accordingly, CBN introduced in 1990, the risk-weighted measure of capital adequacy ratio recommended by the Basle committee of bank for international settlements. Other measures to deal with the insurrection included the prudential guidelines, mandatory uniform accounting standard for licensed banks, establishment of Nigerian Deposit Insurance Corporation (NDIC) in 1989, Banks and Other Financial Institutions Decree (BOFID) of 1991, and many more. 
It became particularly worrisome that in spite of the growing number of banks and the existing competition, the private sector was still fund-starved or had to contend with very high cost of capital. Both situations were detrimental to private sector development. In other words, the financial sector did not only lack the capacity to grow the real sector, but there was also strong evidence of financial distress in the system indicated by capital inadequacy, illiquidity, weak management, inadequate regulation, etc. (Nwankwo, 2013). Between 1994 and 2003, about 36 banks in Nigeria collapsed, most of them due to capital inadequacy, small size, and unethical practices (Mordi, 2004). The CBN surveillance reports of 2004 shows that of the 86 commercial banks in operation, 62 were sound, 13 were marginal, and 11 were unsound. The banking sector consolidation was therefore aimed at improving domestic and international competitiveness of Nigerian banks as well as strengthening them to serve the real sector better (Ezeoha, 2007).

Since then, an unprecedented reform process through merger and acquisitions had taken place among banks in the country. Banks were given ultimatum to raise their capital base to N25 billion (about 167 million USD) individually or through merger and acquisition by 31 December 2006 . But years after the completion of the exercise, the dusts have not settled, as there are still anxieties arising from unemployment, management of banks' assets and liabilities, adequacy of banks' asset base to support the real sector, and profitability.

\subsection{Statement of the Problem}

It is no longer arguable that a vibrant financial sector is instrumental to a virile real sector. Before 2004, the Nigerian financial sector had in some sort milk-dried the real sector. Then, while factories were closing or relocating to other countries, the financial sector was declaring profits; profits from fringe or arbitrage processes involving foreign exchange trading and such like activities crowded out funds and kept the real sector operators always worse off. Besides, with such hardly sustainable policy spin-offs, these frail looking banks were susceptible to economic shock, and did not have the capacity to support investment in the real sector. Not even the merchant banks, designed to provide long term finance, could embark on intermediate term financing. At the root of this disability was inadequate asset base. Given the importance of asset quality and management in the determination of the strength of a bank, and given that reasonable period has elapsed since the completion of the consolidation exercise, this study examine the effect of consolidation on the financial leverage, efficiency and profitability of Nigerian banks five years after the consolidation.

\subsection{Research Question and Hypothesis}

The following research question was formulated for this work: Are there significant effects of the post-bank consolidation asset-base on the financial leverage, efficiency, and profitability of Nigerian banks? We have also conjectured the following statement: There is no significant effect of the post-bank consolidation asset-base on the financial leverage, efficiency, and profitability of Nigerian banks. We trust the result will be a useful tool for counterfactual analysis of government discretionary policies and interventions. It will also serve as an appraisal material for both CBN and shareholders of banks as well as provide grounded reference on bank consolidation for students and researchers alike.

\section{Literature Review}

\subsection{Related Theories}

While it may seem rather elementary to review the various definitions of bank and banking, it will suffice to provide a framework for bank consolidation by referring to the Nigeria's Banks and other Financial Institutions Act (BOFIA) 2001 definition of bank which in addition to the traditional role of receiving deposit and issuing loans included fiduciary services like consultancy, management of clients' investment portfolios, international trade expeditions, actuarial services, and capital market business. Again, if we accept that consolidation is synonymous with merging, then bank consolidation must be the merging of banks to achieve increased intermediation process, financial sector stability, economic growth, increased capital base, optimum liquidity and capitalization of stock market. Nigerian government, through CBN adopted this process in the nation's financial system to sanitize and save the industry from collapse. Event watchers would remember that all was not certainly well in the nation's banking system between 2001 and 2005. According to Soludo (2005), there were anxieties and uncertainties as there were mismanagement, sharp practices, intrigues and endless power tussles between the board and management of many banks in the country which set the bank on the path of insolvency.

Soludo's action was founded in classical theory of monetary policy, which when stripped down implies that recapitalization of banks increases the stock of loanable funds which should lead to a fall in interest rate and therefore stimulate demand for investment funds. (Kates 1998). However, the driver of the process was arguably interventionist in character, and this gives credence to Keynesian theory. The process was guided through space 
and time by government thus deviating from the prescription of Adam Smith about the existence of an invisible hand. So, in the case of Nigeria's consolidation, there was a visible hand of government agency. Thirdly, Sathye (2002) argues that the process also rubs on the concentration theory which involves the merger of say two large banks to form one giant bank in order to enjoy certain degree of control in the industry. Alternatively, the theory explains the essence of consolidation in the light of economies of scale enjoyed in capital efficiency (Demirgue-Kunt \& Levine, 2000). Finally, Aggarwal (2012) states that usually the motives for consolidation in advanced economies are market driven factors such as organizational structure and firm character. In emerging economies, the motives are government driven and often have to do with stability, financial deepening and financial distress. The a fortiori proposition of this theory is that small sized banks do not enjoy economies of scale, are likely to face financial crisis, and have relatively lower capital efficiency rate.

\subsection{Pre-Consolidation Banking Challenges}

Before the recapitalization process the banking industry in Nigeria faced quite a number of challenges some of which in our opinion are similar in character to the causes of the first banking instability in Nigeria's history. They included poor quality assets, under-capitalization, weak corporate governance practices, gross insider abuse, poor ethics, and lack of professional discipline. These factors provided scope for the 2014 reform agenda. (Ezeoha, 2007; Nwankwo, 2013). The exercise was a proactive action to increase the responsiveness of Nigerian banks towards global competitiveness. Ezeoha (2007) noted that the capital bases of Nigerian banks before consolidation range between N15 billion and N20 billion, the major reason they were unsuitable for 'big-ticket' deals. Similar despicable remarks were also made of Nigerian bank's awful ethical and professional conducts, such as resorting to sharp practices, and engagement in businesses not classified as banking. For poor corporate governance practices, there were several instances where board members and management staff failed to uphold and promote the basic pillars of sound corporate governance because they were preoccupied with the attainment of narrowly defined interests. The symptoms of this include high turnover in the board and management staff, inaccurate reporting, and non-compliance with regulatory requirements. On gross insider abuse, Ezeoha (2007) argued that one area where this issue was pronounced was the credit function. There were several cases of huge non-performing insider-related credit abuses as loans were granted without securities or due diligence analysis, leading to huge unsecured risk assets. For instance, NDIC 2004 annual report showed that the ratio of non-performing credit to shareholders' funds deteriorated from 90 percent in 2003 to 105 percent in 2004. This meant that the shareholders' funds had been completely wiped out by the non-performing or unsecured credit portfolio (Ezeoha, 2007).

Besides, there was also an unhealthy practice of over-reliance on government deposits which turned out to constitute over 50 percent of total deposits. Instability also arose from reliance on few high net worth depositors along with shabby treatment of small savers. In fact, it was in response to this situation, coupled with the need to accord SMEs their priority, that the Bankers' committee mounted the Small and Medium Enterprises Equity Investment Scheme (SMEEIS) with a view to redirecting credit flows to the sub-sector. The dominance of a few big banks upon the smaller ones with few branches also constituted challenge.

In recent years, there has been great concern on the management of banks' assets and liabilities because of large scale financial distress. The experience of many countries including Nigeria indicates that regulation and supervision are essential for a stable financial system, and that the need becomes greater as the number and variety of financial institutions increase (Adekoya \& Oyetoye, 2007). Bank consolidation entails not only supervision or enforcement of rules and regulations, but also unwavering financial judgments concerning the soundness of bank assets, its capital adequacy and management skill (Volcker, 1992). Effective consolidation leads to healthy banking industry. And to maintain confidence in the banking sector, the monetary authorities have to ensure that banks play by the rules and ethics of the industry. In Nigeria, we owe the origin of banking instability to high level inconsistencies in the behavior of the foreign banks towards indigenous entrepreneurs such as unwillingness to provide credit to indigenous entrepreneurs, which led to agitations to establish indigenous banks. Following these agitations against British exploitation, the first indigenous banks, Industrial and Commercial Bank, was established in 1929. This bank along with other indigenous banks established thereafter failed largely due to undercapitalization, professional incompetency, rapid expansion programmes, dishonesty, fraud, competition, and absence of banking regulations (Igweike 2008). For instance, some of these banks indulged in overzealous granting of unsecured credit facility to indigenous businessmen leading to huge and largely unsustainable credit risk. Umah (2009). The recommendation of the Paton Commission of Inquiry that followed the dramatic failure led to the promulgation of The Banking Ordinance of 1952 that marked the beginning of banking regulation in Nigeria. The ordinance prescribed minimum capital requirements for all banks as well as maintenance of an adequate degree of liquidity deemed satisfactory to the monetary authority. 
In the area of supervision and control, CBN, which was established in 1958 and commenced operations in 1959 used the instrumentality of its monetary policy circulars, issued annually, to maintain direct control and supervise the activities of all commercial bank in Nigeria by fixing their liquidity ratio, capital base, reserve requirements, interest rates (for deposit and lending) and credit ceiling.

Several empirical studies have been carried out to ascertain the true impact of bank consolidation. Adegbagu and Olokoye (2008) did a descriptive analysis centred on the equality of means of pre and post consolidation eras and found no statistical difference between the two periods with respect to the following profitability ratios: yield on earning asset, return on equity, and return on assets. Somoye (2008), examined the effect of government induced bank consolidation on the macro-economic performance of Nigeria, and concluded that consolidation did not significantly improve the overall bank performance to drive the economy toward sustainable development. Umah (2009) investigated the effect of consolidation on employment and found that recapitalization-induced increase in total assets and domestic branches actually caused 62 percent employment in the banking industry. This conclusion however lacked statistical evidence for net employment. Samuel (2010) showed the existence of strong and positive relationships between banking sector reforms and economic growth. Again, these relationships did not express or identify the causes and/or the extent of effects among the variables studied. Also, Kehinde and Kareem (2012) estimated the effect of bank consolidation on SME financing and concluded that this phenomenon did not enhance SMEs access to finance.

This study would at first seem to be like a confirmation study given that it uses ratios that have been applied by others, it adopts test of means, which again was conducted earlier, and it formulated a regression model, as have been attempted by other empirical works. However, this work departs from others in term of the following: it examines three classifications of ratios that are not only critical to performance but are also relative functions of asset base: financial leverage (risk), assets efficiency, and profitability. Secondly, it adopts not only test of two means to identify significant differences, but it also sought to establish the source(s) of the differences by applying the multiple regression analysis, not by pooling the time series data, but by analyzing the year-by-year differences.

\subsection{Asset Base}

The asset base of a firm is the total value of tangible and intangible assets or benefits in the books of or owned by a bank which are used in the ordinary activities of the bank in generating income, determined by their book value, market value or residual value, including cash, machinery, inventory, land, building, enforceable claims, intellectual property rights, and goodwill. (Wood \& Sangster, 2012; Kieso \& Weygandt, 2004). In strict accounting principles, asset is one side of a coin where liabilities and owners' equity are the other side. The basic accounting logic states that long term liability plus owners' equity must equal net assets. In other words, funds from owners plus borrowed funds are used to purchase the assets that must then be utilized in the ordinary business of the firm. This basic principle gives credence to the following facts: first, bank recapitalization through owners' equity or long term liability ends up increasing the asset stock of the firm. While it is not directly the focus of this work to assess the effect of liability or equity, it should be mentioned that capital structure does affect the stability of the bank. Second, asset quality commands cash flow of a firm. And third, the investment decision that transforms capital into asset must be diligently undertaken. Thus, success of the post consolidation exercise could be evaluated in terms of the incremental asset bases' sensitivity to financial risk or financial leverage, efficient utilization of financial resources, and profitability. Accordingly, the following financial ratios are relevant and will be used as our analytical instruments: (1) long-term debt-to-fixed assets ratio, which measures the percentage of total fixed assets provided by creditors and therefore estimates the ability of the banks to absorb financial risks, (2) assets turnover ratio, which measures the efficiency of assets to generate revenue, and (3) return on assets ratio, which measures the overall profitability of assets. Thus, this study proposes to cover three important measures of financial analysis with respect to changes in the asset bases of Nigerian banks: leverage, efficiency and profitability.

\section{Method}

This section discusses the research methods and procedures followed, taking into account the reliability and validity of the entire research process. The study involves cross sectional and time series data of quoted Nigerian banks for the periods 2000 to 2004 designated as pre-consolidation era and 2008 to 2012 designated as post-consolidation era. Cross-sectional data of 30 pre-consolidation banks and 16 post-consolidation banks were collected in respect of the following variables: Fixed assets, long term debt, revenue, and profit-after-tax. Similarly, time series data were classified into two eras, as stated above, to enable us estimate the changes between the two eras. To that extent, equal periods were allotted to each era such that the pre-consolidation era 
consisted of five years ending in the pen-ultimate year of consolidation exercise, and the post consolidation era commencing in 2008.

Two distinct statistical procedures were adopted, and in each procedure, we considered relative rather than absolute inputs, which suggested the calculation of the aforementioned ratios. The first procedure, paired sample $t$-test, involved testing the difference of two means with an assumption that both means are from two dependent samples (Mason, Lind, \& Marchal, 2005; Cooper \& Schlindler, 2005). This tool is suitable because its requirement is consistent with the study objective, which is characterized by a measurement of pre-consolidation bank performance in financial leverage, bank efficiency and profitability, followed by an intervention represented by consolidation exercise, and then another measurement in the post-consolidation era. Ultimately, the mean for 2004 was compared with the means of 2008 through 2012, and in line with the assumption of consistency and dependency, the mean for 2004 was drawn from a sample of 16 pre-consolidation banks. Paired $\mathrm{t}$-test is given as

$$
t=\frac{\mathrm{d}}{S d / \sqrt{n}}
$$

with n-1 degrees of freedom, where $d$ equals the mean of the difference between paired or related observations, $s_{d}$ equals the standard deviation of the distribution of the differences between the paired or related observations, and $n$ equals the number of paired observations. The two-tailed $p$-value is 0.05 and the null hypothesis is: Ho: $\mu$ $=0$; this means that the sample differences in the appraised paired values could have come from a population with a mean of zero, and if so, then the null hypothesis could be expressed thus: there is no mean difference between the pre-consolidation and post consolidation eras in the specified performance indicators. The decision rule is to reject null hypothesis (Ho) if t-score calculated falls outside the critical region of 2.131.

The second procedure involved formulating multiple regression models that could evaluate the power of asset efficiency and profitability ratios to explain changes in financial leverage. The aim is to test for bank stability that arises from efficient utilization of fixed assets, sound investment decision, avoidance of financial risk-based vulnerability, and optimal revenue-driven liquidity. The models were formulated with ratio data for 2004 and 2012, each representing end year for their respective eras. Thereafter, we conducted an analysis of differences between the two models by examining the independent variables' explanatory powers to cause changes in the dependent variable. This became the basis for inference-based conclusions. This procedure was preferred to a pooled data analysis because it allowed us to see the year-by-year changes in the two eras, which is more critical to this study than any aggregate change.

Thus, assuming a functional relationship between dependent variable (financial leverage, FL) and two independent variables (efficiency, EF and profitability, PF), the following multiple regression model is formulated:

$$
F L=f(E F, P F)
$$

and given a linear relationship, the following regression line is obtained:

$$
F L=\beta_{o}+\beta_{1}(E F)+\beta_{2}(P F)+\mu
$$

where $\beta_{o}$ equals the intercept of $F L$ axis; $\beta_{1}$ and $\beta_{2}$ are the parameters of the independent variables $(E F$ and $P F)$ and $\boldsymbol{\mu}$ is the random variable explained away in order to estimate the effect of $E F$ and $P F$ on $F L$. The estimates of the true parameters $\beta_{o}, \beta_{1}$ and $\beta_{2}$ of the determinants $E F$ and $P F$ are symbolized as follows:

$$
F L=\beta_{o}+\beta_{1}(\tilde{E F})+\beta_{2}(\tilde{P F})+\dot{\varepsilon}
$$

where $\varepsilon$ equals estimate of the random variables $\mu$. With a $p$-value of 0.05 , we ascertained the explanatory power of the coefficient of multiple determination $\left(\mathrm{R}^{2}\right)$ using $f$-test, and stated the null hypothesis as: Ho: $\beta_{1}=\beta_{2}=0$, implying that the net regression coefficient in the population is zero. Next, we evaluated each of the partial regression coefficients using $t$-test. This is to establish the independent variable with higher explanatory power. The null hypothesis, here, is $H o: \beta_{1}=0, \beta_{2}=0$, implying that the value of $\beta_{1}$ or $\beta_{2}$ in the population is equal to zero. The degree of freedom is of the form: $n-(k+1)$, where $\mathrm{n}=$ number of banks, and $\mathrm{k}=$ number of independent variables. This gave 27 and 13 for 2004 and 2012 respectively. The two models are stated below:

$$
\begin{aligned}
& F L_{2004}=\beta_{o}+\beta_{1}\left(\tilde{E} F_{2004}\right)+\beta_{2}\left(\tilde{P F} F_{2004}\right)+\dot{\varepsilon} \\
& F L_{2012}=\beta_{o}+\beta_{1}\left(\tilde{E} F_{2012}\right)+\beta_{2}\left(\tilde{P} F_{2012}\right)+\dot{\varepsilon}
\end{aligned}
$$




\section{Results and Discussions}

Table 1. Paired samples test for pre and post consolidation banks-base year equals 2004

\begin{tabular}{ccccccc}
\hline \multicolumn{2}{c}{ Paired Variables } & Paired Mean Differences & Std. Deviation & $\mathrm{t}$ & $\mathrm{df}$ & Sig. (2-tailed) \\
\hline Pair 1 & FL04 - FRR08 & 1.387824 & 2.611873 & $2.125^{* *}$ & 15 & .051 \\
Pair 2 & FL04 - FRR09 & 1.871720 & 2.405059 & $3.113^{*}$ & 15 & .007 \\
Pair 3 & FL04 - FRR10 & 1.773373 & 2.604733 & $2.723^{*}$ & 15 & .016 \\
Pair 4 & FL04 - FRR11 & 1.619670 & 2.451774 & $2.642^{*}$ & 15 & .018 \\
Pair 5 & FL04 - FRR12 & 1.274174 & 2.704455 & $1.885^{* *}$ & 15 & .079 \\
Pair 6 & EF04 - EFR08 & .705036 & 3.719885 & .758 & 15 & .460 \\
Pair 7 & EF04 - EFR09 & .866528 & 3.925920 & .883 & 15 & .391 \\
Pair 8 & EF04 - EFR10 & 1.023202 & 3.695207 & 1.108 & 15 & .285 \\
Pair 9 & EF04 - EFR11 & .983664 & 3.784565 & 1.040 & 15 & .315 \\
Pair 10 & EF04 - EFR12 & .382573 & 3.884665 & .394 & 15 & .699 \\
Pair 11 & PF04 - PPR08 & .821896 & 3.496462 & .940 & 15 & .362 \\
Pair 12 & PF04 - PPR09 & 1.227801 & 3.587622 & 1.369 & 15 & .191 \\
Pair 13 & PF04 - PPR10 & .460445 & 3.229718 & .570 & 15 & .577 \\
Pair 14 & PF04 - PPR11 & .546627 & 3.572059 & .612 & 15 & .550 \\
Pair 15 & PF04 - PPR12 & .383936 & 3.250065 & .473 & 15 & .643
\end{tabular}

Source: SPSS version 17 output; ${ }^{*}$ Statistical significance for $\mathrm{p} \leq 0.5 ; * *$ Statistical significance for $\mathrm{p} \leq 0.10$.

The paired samples t-test for financial leverage shows significant differences between pre-consolidation year 2004 and post-consolidation years 2009, 2010, and 2011, whereas 2008 is just on the fringe with a p-value of 0.051 , and at $\mathrm{p} \leq 0.10,2012$ was also significant. In other words, long-term debt-to-fixed assets ratio was significantly higher in the pre-consolidation era than in the post-consolidation era at $p \leq 0.10$, as they all appeared to have positive differences. This is an indication of lower financial risk, lower vulnerability and greater financial stability in the post-consolidation era. Next is asset utilization efficiency of banks, measured by assets turnover ratio. Here, the hypothesis that there is no significant difference between the two eras was not rejected as shown in the output of our paired samples test. This implies that there is, relatively, less efficiency in the utilization of assets in the post-consolidation era than in the pre-consolidation era as revenue did not grow progressively along with the growth in asset base. Finally, the hypothesis for profitability was also not rejected as shown in the paired samples test, an indication that return on asset ratio of banks remained the same in spite of the recapitalization. While this may not suggest any disadvantage should both variables in the calculation of the ratio change in equal proportion, it simply implies that the new asset base did not alter the degree of operating leverage associated with changes in fixed cost. If that is true of profitability, then it should be reasoned that the operating risk of post-consolidation banks will remain unchanged.

Table 2. Multiple regression coefficients dependent variable: financial risk

\begin{tabular}{|c|c|c|c|c|c|c|c|c|}
\hline Year & $\mathbf{R}^{2}$ & f-test & Sig. (f-test) & Para-meters & Independent Variables & Coef. & t-test & Sig (t-test) \\
\hline \multirow[t]{3}{*}{2004} & 0.214 & $3.858^{*}$ & 0.039 & $\beta_{0}$ & Constant & 1.612 & $2.700 *$ & 0.012 \\
\hline & & & & $\beta_{1}$ & $\mathrm{EF}$ & 0.324 & $2.574^{*}$ & 0.016 \\
\hline & & & & $\beta_{2}$ & $\mathrm{PF}$ & -0.027 & -0.762 & 0.453 \\
\hline \multirow[t]{3}{*}{2012} & 0.555 & $8.107^{*}$ & 0.005 & $\beta_{0}$ & Constant & 0.645 & 1.682 & 0.117 \\
\hline & & & & $\beta_{1}$ & $\mathrm{EF}$ & 0.449 & $4.023^{*}$ & 0.001 \\
\hline & & & & $\beta_{2}$ & $\mathrm{PF}$ & -0.603 & -1.427 & 0.177 \\
\hline
\end{tabular}

Source: SPSS version 17 output; *Statistical significance for $\mathrm{p} \leq 0.5$.

Note. f-tabulated for $2004=3.42 ; 2008 \& 2012=3.81 ;$ t-tabulated for $2004=2.052 ;$ for $2008 \& 2012=2.160$. 
The outcome of the multiple regression analyses from both years are notably alike in the following manners: first, only asset efficiency significantly contributed to changes in financial leverage in both years, a phenomenon that literally defies traditional financial thinking, as it connotes that a unit increase in asset efficiency results in 0.324 and 0.234 units increases in financial leverage (risk) in 2004 and 2012 respectively. Recall that in our earlier discussion, at no time was the mean of asset efficiency found to be significantly different between pre- and post-consolidation years. Again, note that the a priori expectation would be a negative effect. This result therefore points to one direction: inefficient utilization of incremental asset base coupled with dysfunctional operating leverage has turned a supposed upside benefit to a downside risk. After all, the degree of operating leverage measures the effect on profit resulting from a given increase in sales when the fixed cost-to-total cost structure is altered. (Adelman \& Marks, 2009) Like a double-edged sword, an increase in fixed cost can have a dramatic or devastating effect on profit or loss if revenue from sales is optimized or sub-optimized respectively. Secondly, profitability causes negative and insignificant changes on financial leverage for both years. That is, one percent increase in profitability causes 0.027 percent and 0.603 percent decrease in financial leverage (risk) respectively. This conforms to basic financial logics that as businesses make profit, they tend to utilize more of internal (retained) capital that exposes them to lesser risk than borrowed funds. (Olowe, 2009; Adelman \& Marks, 2009; HBS, 2002).

\section{Conclusion}

Following the dual analytical procedures undertaken, the results presented mixed feelings, so also is the conclusion drawn. There appeared to be a significant overall positive change in financial leverage at the post-consolidation era. Positive in the sense that financial leverage declined along with financial risk as debt-to-fixed assets ratio is significantly lower in the post-consolidation era. This alludes to a greater stability and lesser vulnerability in the banking industry. Secondly, there is apprehension about sustaining this trend for too long given that post-consolidation assets efficiency did not remarkably differ from pre-consolidation assets efficiency, which inadvertently suggests the case of robbing Paul to pay Peter. Following from above, profitability is unsurprisingly not different in both eras but it is its causal effect on financial leverage that requires overriding attention; the result shows an inverse effect which is in concordance with expected outcome. In summary, while bank consolidation led to reduction in financial leverage, it has not stimulated assets efficiency and profitability enough to settle the dusts and apprehensions in the industry. In spite of this conclusion, it should be noted that we are mindful of the high current ratios usually maintained by banks due to the industry's liquidity preference, and to add, here, that this aspect was excluded in this study because it is not aligned with our study objective. Perhaps, the effect of current ratios may complement our analysis and provide basis for future studies.

\section{References}

Adekanye, F. (2010). The Elements of Banking in Nigeria. Lagos: Fazburn Publishers.

Adekoya, A., \& Oyetoye, E. (2007). Determining the strategic consolidation of the capital base of Nigerian commercial bank. International Journal of Project Management, 19.

Adelman, P., \& Marks, A. (2009). Entrepreneurial Finance. New Jersey: Pearson Prentice Hall.

Aderibigbe, J. O. (1997). Monetary Policy and Financial Reform. Paper presented at the financial programming and analysis workshop organized by Research department of CBN.

Aggarwal, M. (2012). Motive for Consolidation in Indian Banking Sector. International Journal of Marketing Research, 2(9). Retrieved from http://www.ijmra.u/project doc/IJMT_September 2012

Cooper, D., \& Schindler, P. (2005). Business Research Methods (8th ed.). Boston: McGraw-Hill Irwin.

Demirgu Kunt, C., \& Levine, R. (2000). Bank Concentration: Cross Country Evidence. Retrieved from http://www.globalpolicy.org

Ezeoha, A. (2007). Structural effects of Banking Industry Consolidation in Nigeria: A Review. Journal of Banking Regulation, 8. http://dx.doi.org/10.1057/palgrave.jbr.2350044

Harvard Business Essentials. (2003). Finance for Managers: Your Mentor and Guide to Doing Business Effectively. Massachusetts: Harvard Business School Publishing Corporation.

Igweike, K. I. (2008). Law of Banking and Negotiable Instruments. Lagos: Africana First Publishers Ltd.

Kates, A. (1998). Says Laws and the Keynesian Revolution: How Macroeconomic Theory Lost its Way. Edward: Elgard Publishing Ltd. 
Kehinde, \& Kareem. (2012). Impact of Pre and Post Bank Consolidation on the Growth of Nigeria's Economy. International Journal of Business and Management, 8(13).

Kieso, D. E., \& Weygandt, J. J. (2004). Intermediate Accounting. New York: John Wiley and Sons Inc.

Mason, R., Lind, D., \& Marchal, W. (1999). Statistical Techniques in Business And Economics. Boston: McGraw-Hill.

Mordi, C. N. (2004). Institutional framework for the regulation and supervision of the financial sector. Central Bank of Nigeria Bulletin, 28.

Nwankwo, O. (2013). Impact of Pre and Post Bank Consolidation on the Growth of Nigeria's Economy. International Journal of Business and Management, 8(13).

Olakanmi, J. (2012). Financial Institutions Handbook. Abuja: Law Lords Publications.

Ollor, W. G. (2008). Essays on Nigerian Structural Adjustment Programme. Port Harcourt: Hamilton Publishers.

Olowe, A. (2009). Financial Management: Concepts, Financial System and Business Finance. Lagos: Brierly Jones Nig Ltd.

Sathye, M. (2002). The Impact of Foreign Banks on Market Concentration: The case of India. Applied Econometrics and International Development, 2, 7-20.

Soludo, C. (2005). The Imperative of Banking Sector Reforms in Nigeria. A paper presented at the Inauguration of the Consultative Committee on Banking Sector consolidation. Retrieved from http://www.cenbank.org/documents

Somoye, R. (2008). Creating value from Mergers and Acquisitions: The challenges. Harlow: Pearson educational ltd.

Umah, G. (2009). Impact of the Banking Industry Recapitalization on Employment in Nigerian Banks. European Journal of Social Sciences, 11(3).

Wood, F., \& Sangster, A. (2002). Business Accounting (9th ed.). London: Pearson Education Ltd.

\section{Copyrights}

Copyright for this article is retained by the author(s), with first publication rights granted to the journal.

This is an open-access article distributed under the terms and conditions of the Creative Commons Attribution license (http://creativecommons.org/licenses/by/3.0/). 